\title{
Pemberdayaan kelompok masyarakat Kecamatan Tampan Kota Pekanbaru dalam program inovasi teknologi pengering berbasis biomassa yang ramah lingkungan untuk meningkatan kualitas dan kuantitas produk makanan berbahan baku ubi untuk pengembangan agoindustri kripik ubi kayu sebagai produk unggulan daerah
}

\author{
Juandi Muhammad*, Herman, Gimin, Joko Risanto, \& Syahril \\ Universitas Riau \\ *juandi@lecturer.unri.ac.id
}

\begin{abstract}
Abstrak. Potensi sektor pertanian ubi kayu di Kabupaten Tampan Kota Pekanbaru dengan total potensi ubi kayu 11.210 ton (berdasarkan data BPS, 2019). Potensi yang sangat besar tersebut mendorong tumbuhnya UKM bagi kelompok masyarakat untuk memanfaatkan peluang tersebut dalam usaha pengolahan pangan berbahan dasar ubi kayu. Selanjutnya potensi tersebut menjadi peluang bagi pemerintah daerah untuk menciptakan pasar atau produk unggulan daerah serta menjadi daya tarik bagi warga dari luar daerah untuk datang ke Kabupaten Tampan karena dapat membentuk agroindustri di bidang keripik singkong. Daya tarik pengunjung untuk singgah di Kecamatan Tampan juga didukung oleh aspek geografis, transportasi yang mudah dijangkau oleh semua orang. Melalui kegiatan pengabdian masyarakat skema desa binaan sangat tepat diterapkan di Kabupaten Tampan karena dapat membina kelompok UKM sehingga pada akhir kegiatan pengabdian skema desa binaan ini akan terbentuk produk daerah unggulan yang berdaya saing melalui penerapannya. teknologi pengeringan berbasis energi biomassa yang ramah lingkungan, dan penerapan sistem manajemen berbasis IT sehingga pada akhir kegiatan akan menghasilkan desa binaan Agroindustri dengan produk unggulan daerah yang berdaya saing.
\end{abstract}

Kata kunci: biomassa, ubi kayu, pengeringan, teknologi

\begin{abstract}
The potential of the agricultural sector in terms of cassava in Tampan District, Pekanbaru City with a total potential of 11,210 tonnes of cassava (based on BPS data, 2019). This enormous potential has led to the growth of SMEs for community groups to take advantage of these opportunities in the business of producing cassava-based food processing. Furthermore, this potential is an opportunity for local governments to create a market or regional superior product as well as an attraction for citizens from outside the region to come to Tampan District because it can form an agro-industry in the field of cassava chips. The attraction for visitors to stop by at Tampan District is also supported by geographical aspects, transportation that is easily accessible to everyone. Through this community service activity, the fostered village scheme is very appropriate to be applied in Tampan District because it can guide UKM groups so that at the end of the service activities of this guided village scheme will form superior regional products that are competitive through the application of environmentally friendly biomass energy-based drying technology, and the application of ITbased management system so that at the end of the activity it will produce an Agro-Industry target village with regional superior products that are competitive.
\end{abstract}

Keywords: biomass, cassava, drying, technology

To cite this article: Muhammad, J., Herman., Gimin., J. Risanto., \& Syahril. 2020. Pemberdayaan kelompok masyarakat Kecamatan Tampan Kota Pekanbaru dalam program inovasi teknologi pengering berbasis biomassa yang ramah lingkungan untuk meningkatan kualitas dan kuantitas produk makanan berbahan baku ubi untuk pengembangan agoindustri kripik ubi kayu sebagai produk unggulan daerah. Unri Conference Series: Community Engagement 2: 541-549. https://doi.org/10.31258/unricsce.2.541-549

(C) 2020 Authors

Peer-review under responsibility of the organizing committee of Seminar Nasional Pemberdayaan Masyarakat 2020 


\section{PENDAHULUAN}

Proses Perbaikan kualitas olahan yang dilakukan oleh masyarakat di Kecamatan Tampan dalam upaya pengeringan bahan baku Kerupuk telah dilakukan yaitu dengan solusi menerapkan sistim teknologi kolektor Sistim Tenaga Energi Biomassa yang ramah lingkungan sehingga hasilnyapun akan higienis, ternyata telah mampu menyelesaikan masalah pengeringan bahan baku menjadi bahan jadi yang siap untuk diolah (Juandi dan Edisar, 2015, Sumarsono, M. (2006).). Namunpun demikian masih banyak lagi permasalahan yang harus diselesaikan,yaitu masalah pengolahan untuk produksi bahan jadi menjadi bahan siap untuk ke konsumen yang harus disentuh dengan teknologi tepat guna.

Usaha Kerupuk berada di Kecamatan Tampan, Kotamadya Pekanbaru. Kecamatan Tampan yang terkenal dengan daerah sentral home industri, sehingga tidak mengherankan jika banyak masyarakat di Kecamatan Tampan yang melakukan usaha pengolahan Kerupuk. Berdasarkan kondisi tersebut maka di Kecamatan Tampan memiliki potensi dalam bidang usaha olahan kerupuk ubi. Bahan baku olahan kerupuk didapatkan ada yang berasal dari Kecamatan Tampan atau yang berasal dari Kecamatan lainnya di Kota Pekanbaru.

Hasil pengamatan dilapangan menunjukkan bahwa tidak ada dalam masalah penyediaan bahan baku. Hasil pengamatan dilapangan ternyata usaha olahan Kerupuk ikan bawal oleh masyarakat menggunakan pengering system tradisional ternyata juga mengalami permasalahan karena lamanya waktu pengeringan sampai 3 hari, sehingga produktivitas hanya dapat diproses sebesar $30 \mathrm{~kg} / \mathrm{hari}$, dengan mempekerjakan 4 orang tenaga kerja.

Melalui teknologi pengering tenaga energy biomassa dapat menyebabkan hasil olahan kerupuk ikan bawal akan meningkat dan akan meningkatkan pendapatan masyarakat dalam hal hasil olahan kerupuk ikan bawal, sehingga kualitas olahan kerupuk ikan bawal akan segera terwujud di masyarakat Kecamatan Tampan. Penerapan teknologi pengering tenaga energy Biomassa akan menghasilkan olahan kerupuk jangek dan kerupuk ikan bawal berkualitas yang mengalami peningkatan kuantitas secara bersamaan sehingga dapat mempercepat produksi dan meningkatkan inkam pengusaha olahan kerupuk ikan bawal di Kecamatan Tampan Pekanbaru (Juandi, M., \& Haekal, M. R. (2016).

Kecamatan Tampan merupakan salah satu dari 12 kecamatan yang ada di Kota Pekanbaru. Tenayan Raya merupakan pemekaran dari Kecamatan Bukit Raya, ini berdasarkan peraturan daerah Kota Pekanbaru No. 3 tahun 2003 tentang pembentukan Kecamatan Marpoyan Damai, Kecamatan Tenayan Raya, Kecamatan Payung Sekaki dan Kecamatan Rumbai Pesisir.

UKM yang tumbuh di Kecamatan Tampan, sehingga kegiatan perekonomian sector pertanian dapat berpusat pada sektor kegiatan UKM tersebut. Salah satu upaya untuk meningkatkan kesejahteraan UKM adalah dengan melakukan pengolahan hasil pertanian. Pengolahan hasil pertanian atau agroindustri merupakan usaha pengolahan hasil pertanian untuk tujuan peningkatan nilai produk.

\section{Masalah}

Berdasarkan identifikasi tersebut maka permasalahan yang ada di Kecamatan Tampan Kota Pekanbaru, yaitu:

a. Masih menggunakan pengeringan secara tradisional, sehingga target kegiatan ini akan menghasilkan teknologi pengeringan berbasis biomassa.

b. Waktu pengeringan yang lama 3-4 hari, sehingga target kegiatan ini akan menghasilkan teknologi pengeringan yang efesien.

c. Masyarakat belum mengenal teknologi pengeringan berbasis biomassa, sehingga target kegiatan ini akan memberikan sosialisasi dan transfer alih teknologi.

Berdasarkan identifikasi tersebut maka permasalahan yang ada di Kecamatan Tampan Kota Pekanbaru, yaitu:

a. Masih menggunakan pengeringan secara tradisional, sehingga target kegiatan ini akan menghasilkan teknologi pengeringan berbasis biomassa.

b. Waktu pengeringan yang lama 3-4 hari, sehingga target kegiatan ini akan menghasilkan teknologi pengeringan yang efesien.

c. Masyarakat belum mengenal teknologi pengeringan berbasis biomassa, sehingga target kegiatan ini akan memberikan sosialisasi dan transfer alih teknologi.

\section{METODE PENERAPAN}

\section{Lokasi Kegiatan Pengabdian}

Lokasi Kegiatan pengabdian ini berada di Kelurahan Tuah Madani RW 01, Kecamatan Tampan, Kota Pekanbaru Provinsi Riau. 


\section{Waktu Kegiatan}

Kegiatan ini bersamaan dengan KUKERTA terintegrasi dengan durasi kegiatan sebanyak 30 kali pertemuan mencakup kedalam semua kegiatan mahasiswa yang KUKERTA di Kelurahan Tuah Madani RW 01, Kecamatan Tampan, Kota Pekanbaru Provinsi Riau

\section{Alat dan Bahan}

Alat dan bahan yang digunakan dalam pengabdian ini ditunjukkan dalam Tabel .1 sebagai berikut:

Tabel 1. Alat dan bahan

\begin{tabular}{cll}
\hline No. & Alat dan Bahan & Fungsi \\
\hline 1 & Bahan baku kerupuk & Sebagai bahan objek pengeringan \\
2 & Limbah tempurung kelapa & Sumber energi biomassa \\
3 & Seng & Sebagai atap alat pengering \\
4 & Triplek & Sebagai dinding alat pengering \\
5 & Busa & Sebagai isolator \\
6 & Kayu Broti & Sebagai penyangga alat pengering \\
7 & Paku & Sebagai perekat \\
8 & Drum & Sebagai ruang energi biomassa \\
9 & Kayu & Sebagai rak tempat kerupuk \\
10 & Cat hitam & Sebagai penyerap panas \\
11 & Plat seng & Sebagai dinding dan cerobong \\
12 & Stopwatch & Sebagai pengukur waktu pengeringan \\
13 & Timbangan digital & Sebagai pengukur massa kerupuk \\
14 & Timbangan analog & Sebagai timbangan massa tempurung \\
15 & Termometer & Sebagai pengukur temperatur ruang pengering \\
16 & Lem cap kambing & Sebagai perekat busa dengan triplek \\
\hline
\end{tabular}

\section{Rancang Bangun Alat Pengering Tipe Kabinet}

Ruang pengering tipe kabinet merupakan pengering yang ramahlingkungan. Adapun bentuk dari alat pengering dapat dilihat pada Gambar 1 berikut ini:

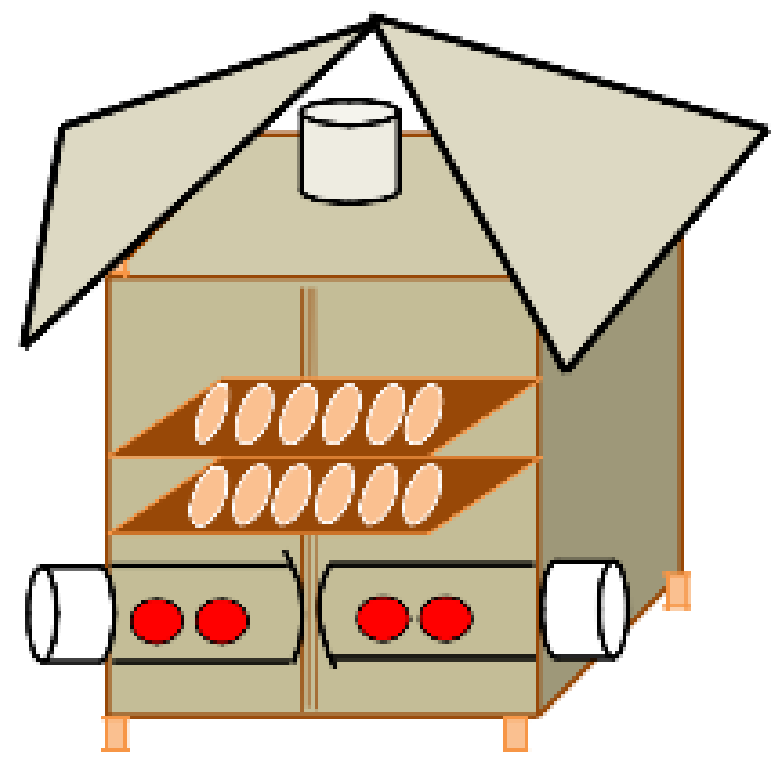

Gambar 1. Rancangan alat pengering tipe kabinet 
Alat pengering tipe kabinet mempunyai spesifikasi sebagai berikut :

a. Luas ruangan pengering dengan ukuran $1,32 \mathrm{~m} \times 0,85 \mathrm{~m} \times 1,13 \mathrm{~m}$.

b. Atap memiliki ukuran panjang 1,54 m, lebar $1,17 \mathrm{~m}$, dan tinggi $0,55 \mathrm{~m}$.

c. Memiliki cerobong dengan diameter $0,16 \mathrm{~m}$ dan tinggi $0,28 \mathrm{~m}$.

d. Terdapat 2 buah rak pengering yang masing-masing memiliki panjang $1,25 \mathrm{~m}$ dan lebar $0,71 \mathrm{~m}$ dan jarak antar rak $0,04 \mathrm{~m}$.

e. Terdapat 4 buah kaki penyangga pada alat pengering yang masing-masing memiliki tinggi $0,16 \mathrm{~m}$.

f. Ruang energi biomassa terdiri dari 2 buah drum berbentuk silinder yang masing-masing memiliki diameter $0,48 \mathrm{~m}$ dan panjang $0,55 \mathrm{~m}$.Drum ini diberi penyangga dengan tinggi $0,05 \mathrm{~m}$.

g. Dilengkapi dengan thermometer Celsius untuk skala penunjuk temperatur ruangan.

h. Bahan sumber energi biomassa dari limbah tempurung kelapa.

\section{PEMBAHASAN DAN KETERCAPAIAN SASARAN}

\section{Luaran Utama Kegiatan}

Biomassa dapat digunakan sebagai sumber energy (Asnawi. 2002). Teknologi diperlukan untuk dapat memanfaatkan energy guna keperluan manusia (Irawan B. 2001. Luaran utama kegiatan pengabdian ini adalah menghasilkan teknologi pengeringan bahan baku kerupuk berbasis biomassa, seperti ditunjukkan pada Gambar 2.

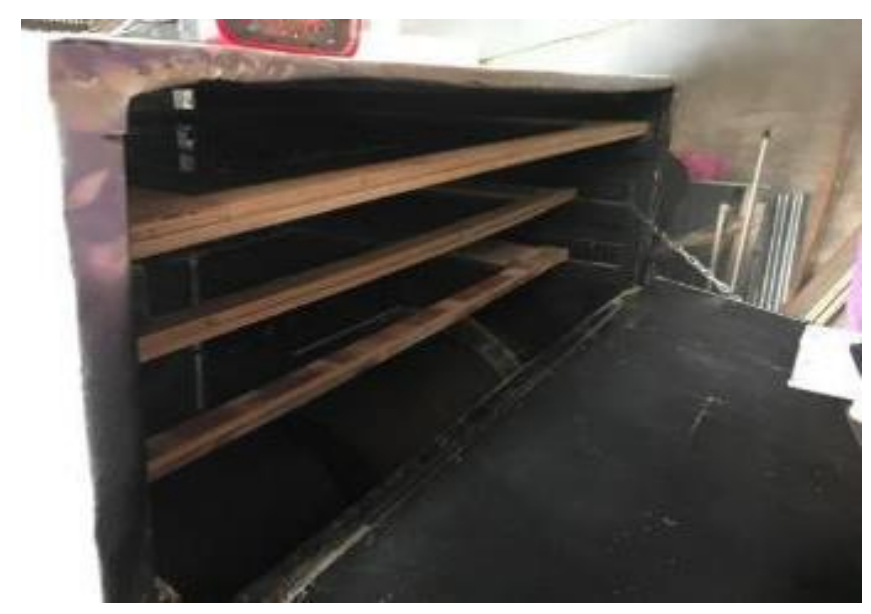

Gambar 2. Luaran utama kegiatan pengabdian

Gambar 2 menunjukkan luaran utama kegiatan pengabdian, yaitu berupa alat teknologi pengering bahan baku kerupuk berbasis energy biomassa. Hasil pengukuran penurunan kadar air dan distribusi suhu dalam ruang pengering ditunjukkan dalam Gambar 3 dan Gambar 4. Berdasrakan Gambar 3 dapat dilihat bahwa penurunan kadar air sampai menit ke 60 sudah di bawah $8 \%$, untuk masing-masing posisi sampel yang diuji. Sedangkan berdasarkan Gambar 4 dapat dikatakan bahwa distribusi temperature bisa berkisar 45 sampai 70 derajat Celsius. 


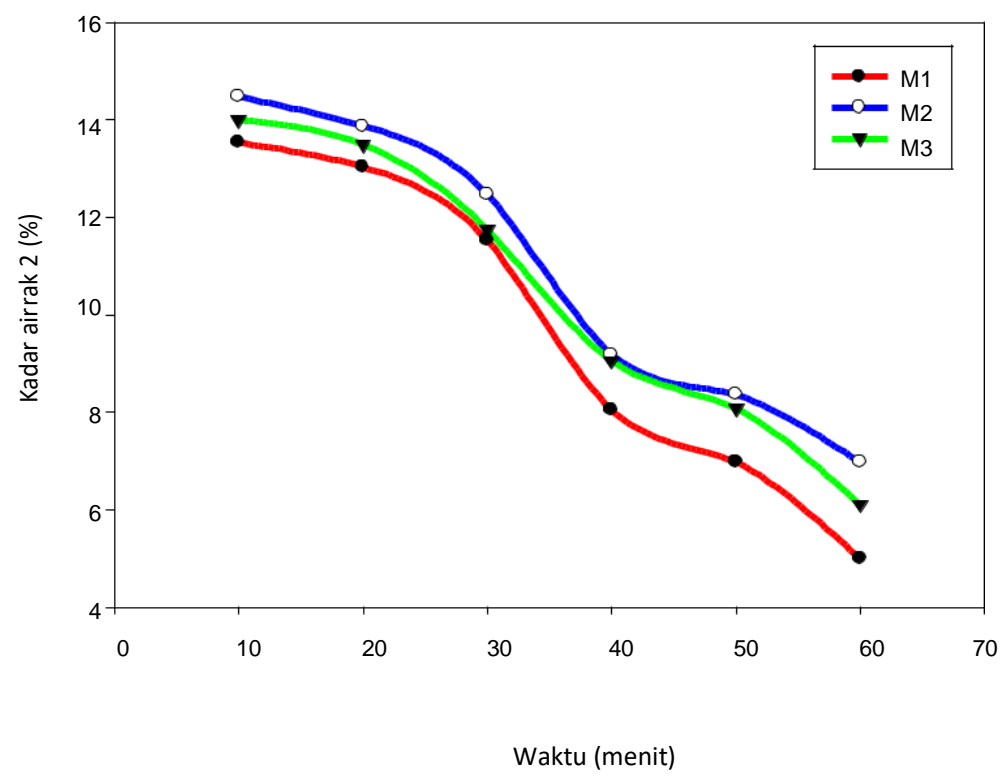

Gambar 3. Grafik hubungan antara kadar air terhadap waktu

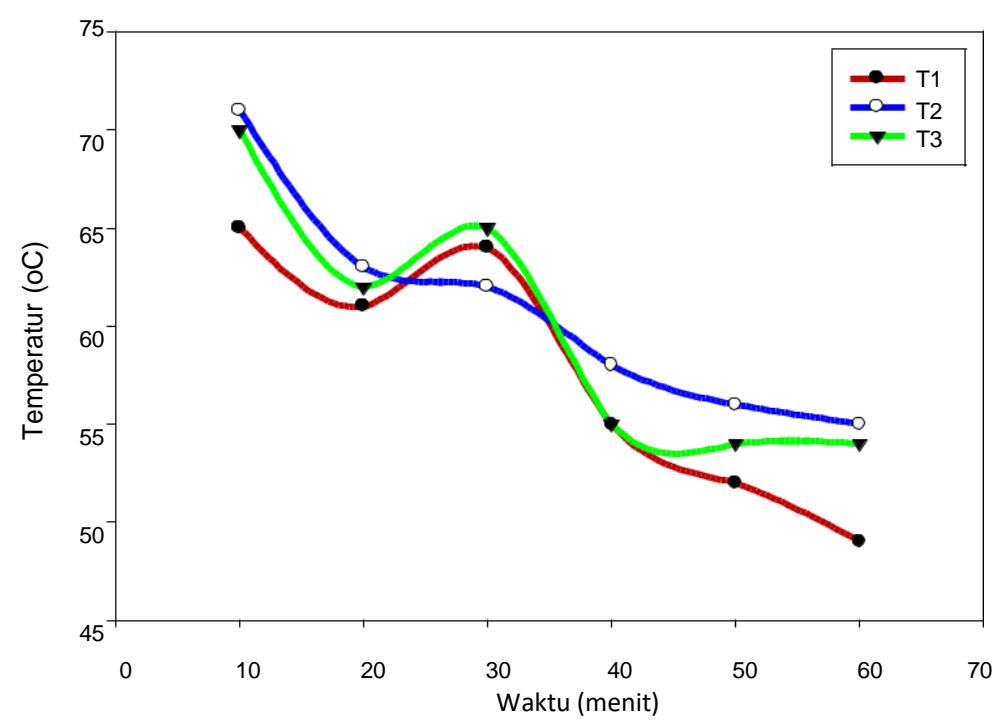

Gambar 4. Distribusi suhu dalam ruang pengering

Gambar 5, tim Kukerta terintegrasi telah melakukan sosialisasi teknologi pengering berbasis biomassa. Alat teknologi ini memiliki efesiensi kerja yang baik telah berhasil menghasilkan kerupuk yang berkualitas baik. 


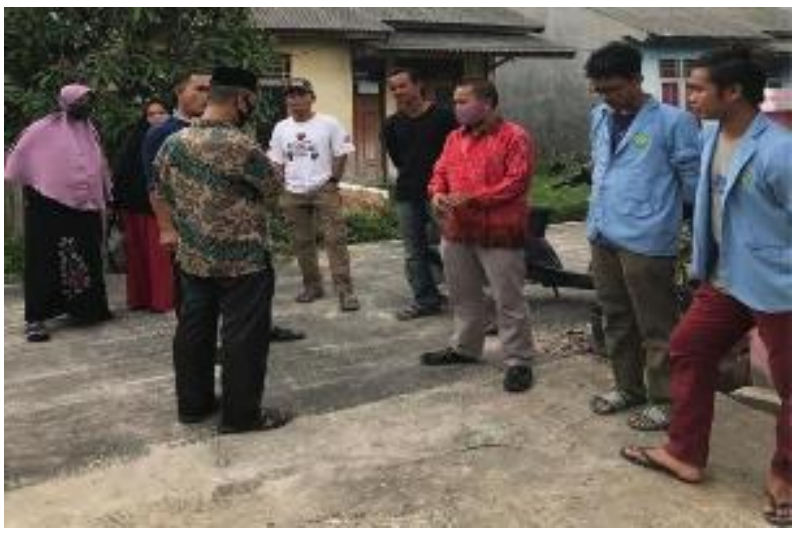

Gambar 5. Sosialisasi Teknologi Pengering berbasis biomassa

\section{Keunggulan dan kelemahan kegiatan}

Adapun keunggulan kegiatan pengabdian ini terletak pada efesiensi waktu dan peningkatan manajemen produksi. Secara efesiensi waktu masyarakat hanya memerlukan waktu 60 menit untuk mengeringkan bahan baku kerupuk kulit lembu, dan peningkatan manajemen produksi ditandai dengan tidak perlu lagi masyarakat melakukan pengawasan, artinya terhindar dari gangguan hewan ternak, anak-anak dan hujan, tentu hal ini akan dapat meningkatkan produksi bahkan lebih higines, tergantuan pada kesediaan bahan baku yang akan di olah (Gambar 6). Hasil kegiatan pengabdian ini menunjukkan antusias yang tinggi dari masyarakat dimana produksi dapat diperoleh hanya dalam waktu 1 jam dengan temperature dalam ruang pengering mencapai 45 derajat Celsius.

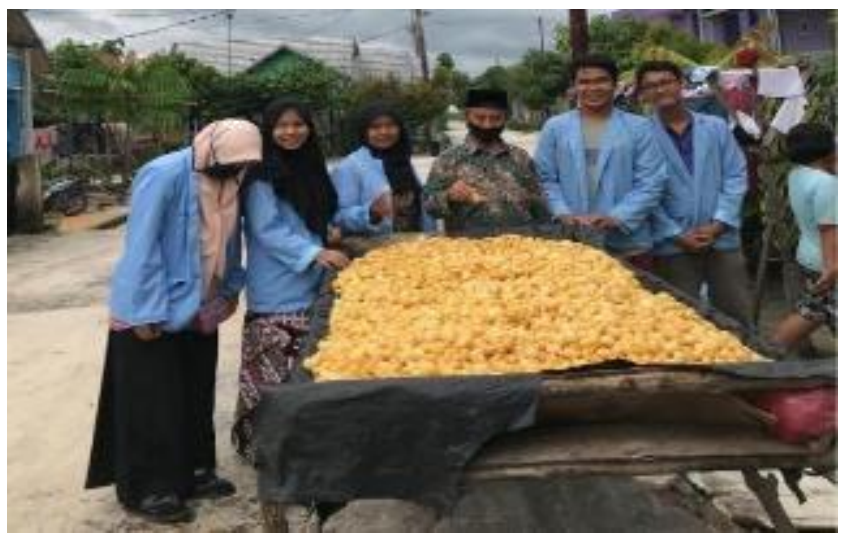

Gambar 6. Bahan baku kerupuk kulit lembu yang akan dikeringkan

Gambar 6 menunjukkan bahan baku yang akan menjadi praktek penggunaan alat teknologi pengering berbasis biomassa, dimana bahan baku yang akan dikeringkan di letakkan dalam rak-rak pengering.

\section{Tingkat Kepuasan pelaksanaan kegiatan}

Tingkat Kepuasan pelaksanaan kegiatan pengabdian ini terlihat pada Respon masyarakat desa mengenai penyuluhan ini sangat bagus. Banyak masyarakat yang berbondong-bondong ingin mencoba alat. Selain itu juga, masyarakat juga kooperatif saat penyuluhan. Antusias warga terhadap kegiatan pengabdian yang dilakukan, dimana warga yang sedang berjalanpun singgah dan bertanya tentang maksud kegiatan ini, karena tidak semua warga yang diundang dalam kegiatan ini, yang di undang hyanyalah warga yang berprofesi UKM kerupuk.

Tingkat kepuasan warga juga ditandai dengan ucapan terima kasih yang disampaikan warga saat selesai kegiatan sosialisasi teknologi pengering berbasis biomassa., seperti ditunjukkan dalam Gambar 7. 


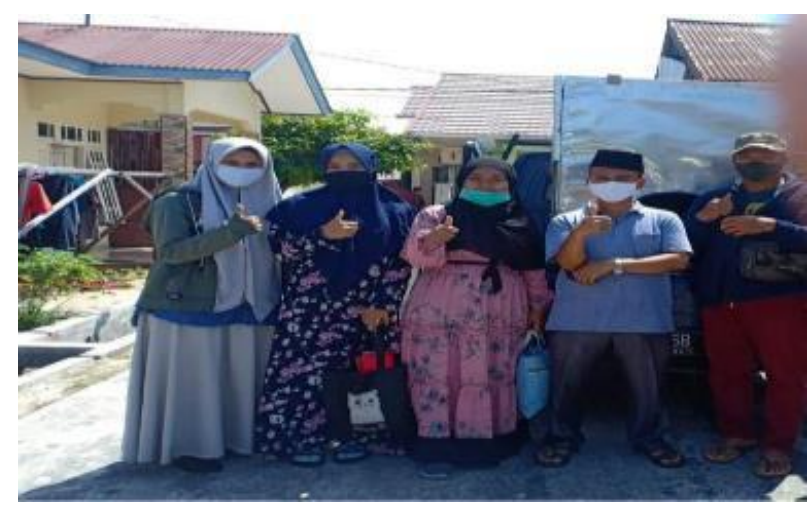

Gambar 7. Ungkapan antusias masyarakat terhadap kegiatan pengabdian

Kegiatan KUKERTA Terintegrasi UR 2020 melaksanakan kegiatan pengabdian kepada masyarakat di Kelurahan Tuah Madani RW 01 dengan judul Pemberdayaan Kelompok Masyarakat Kecamatan Tampan Kota Pekanbaru Dalam Program Inovasi Teknologi Pengering Berbasis Biomassa Yang Ramah Lingkungan Untuk Meningkatan Kualitas Dan Kuantitas Produk Makanan Berbahan Baku Ubi Untuk Pengembangan Agoindustri Kripik Ubi Kayu Sebagai Produk Unggulan Daerah.

Kegiatan pengabdian ini terintegrasi dengan KUKERTA mahasiswa UNRI tahun 2020 terdiri Mhd. Haris Amin 1704113432, Dino Yanuardi 1703113393, Suripman 1703110910, Gita Hamzah 1704113321, Rhiva Permata 1703110782, Sri Mulyani 1706114772, Dhea Ananda Ariyanti 1704113442, Sangkot Hani Rizki 1711122842 , Widia Fitri Novita Sari 1707111549.

Kegiatan ini dilaksanakan di Kelurahan Tuah Madani RW 01 Kecamatan Tampan selama 30 kali pertemuan. Berdasarkan dari tema pengabdian, Kelompok Kukerta ini melaksanakan Penyuluhan Potensi Energi Biomassa yang Ramah Lingkungan, Penyuluhan Penerapan Energi Biomassa yang Ramah Lingkungan untuk Meningatkan Ekonomi Masyarakat, Penerapan Alat Teknologi Pengeringan dan Penyuluhan Pemanfaatan Energi Biomassa yang Ramah Lingkungan untuk Pengeringan. Masyarakat sangat antusias selama kegiatan (Gambar 8).

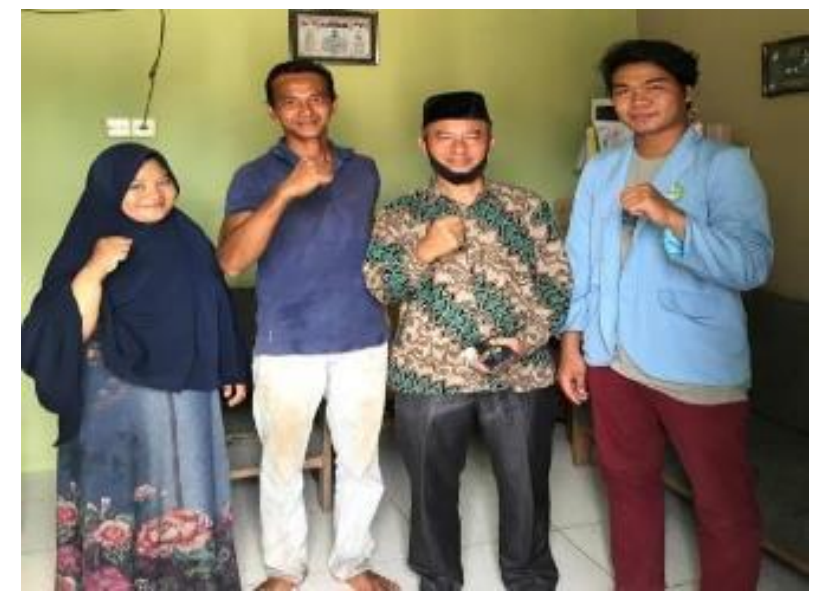

Gambar 8. Antusias masyarakat dalam sosialisasi teknologi biomassa

Antusias kegiatan ini ditandai juga dengan pernyataan Bapak Lurah Tuah Madani atau mewakili mengatakan bahwasanya kegiatan ini mampu menjadi pusat peningkatan ekonomi masyarakat. Hal itu pun juga disetujui oleh Tokoh Masyarakat yang hadir. Selain menjadi ide ekonomi, teknologi pengeringan berbasis energi biomassa ini juga sebagai pendukung dari sisi kesehatan (Gambar 9), Krisman, dkk, (2019). 


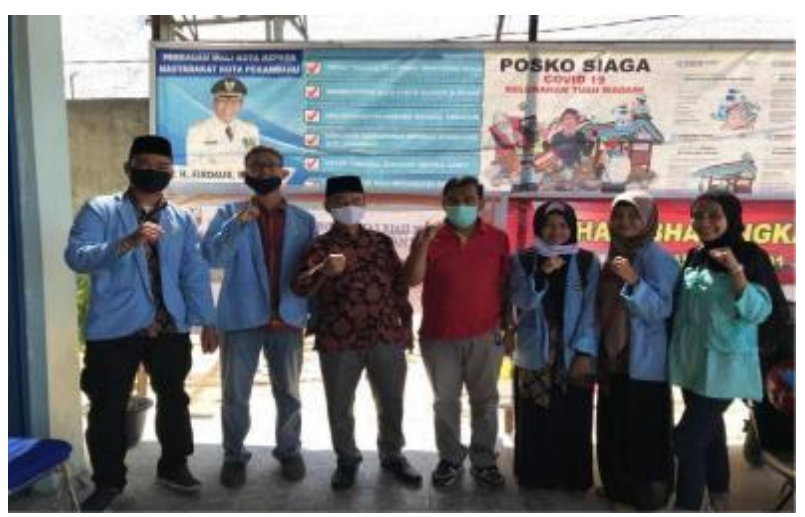

Gambar 9. Antusias terhadap kegiatan yang disampaikan oleh Pak Lurah Tuah Madani

Teknologi dapat digunakan sebagai upaya untuk meningkatkan ekonomi masyarakat (Alma, 2000). Selain adanya penyuluhan tersebut, alat yang menjadi alat bantu pengeringan ini diberikan kepada masyarakat sebagai upaya peningkatan ekonomi.

Tanda keberhasilan dari pelaksanaan kegiatan pengabdian ini ditandai dengan foto bersama sebagai tanda bahwa kegiatan pengabdian ini telah sukses dilaksanakan di Kelurahan madani RW 01 Kecamatan Tampan, Kota Pekanbaru, seperti ditunjukkan dalam Gambar 10.

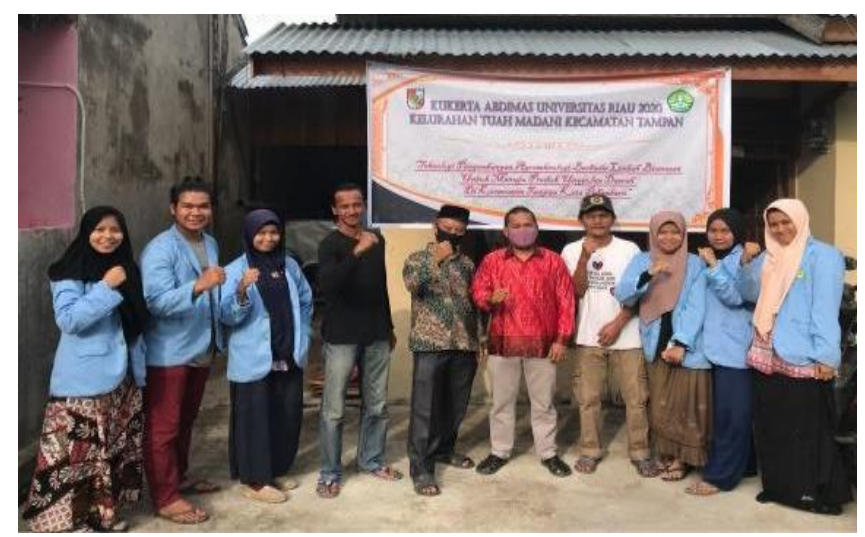

Gambar 10. Foto bersama seusai kegiatan pengabdian

\section{KESIMPULAN}

Berdasarkan hasil pelaksanaan pengabdian pada masyarakat yang telah dilakukan serta analisa, maka dapat diambil kesimpulan yaitu telah berhasil diterapkan teknologi pengeringan berbasis biomassa untuk pengeringan Bahan baku Kerupuk di Kelurahan Tuah Madani RW 1 Kecamatan Tampan Kota Pekanbaru Provinsi Riau. Bahwa masyarakat sangat antusias dalam kegiatan tersebut, dimana produksi ikan asin dapat diperoleh hanya dalam waktu 1 jam dengan temperature dalam ruang pengering mencapai 45 sampai 70 derajat derajat Celsius. Rekomendasi yang diberikan agar masyarakat dapat secara konsisten menerapkan ilmu yang telah diajarkan yaitu penggunaan teknologi pengeringan berbasis biomassa untuk pengeringan bahan baku kerupuk.

\section{UCAPAN TERIMA KASIH}

Ucapan terima kasih kepada LPPM UR yang telah memberi bantuan dana, dan ucapan terimaksih kepada mahasiswa Kukerta yang telah membantu dalam praktek lapangan Bersama Masyarakat. 


\section{DAFTAR PUSTAKA}

Alma, B. 2000. Panduan Kuliah Kewirausahaan. Penerbit Alfabeta, Bandung.

Asnawi. 2002. Aplikasi dan Penerapan Budidaya Kelapa Hibrida. Penerbit Armico. Bandung.

Irawan B. 2001. Penyerapan energy matahari dengan kolektor pelat datar. Jurnal bisnis dan teknologi 9(2):314-318.

Juandi, M., \& Haekal, M. R. 2016. Karakterisasi Pengaruh Suhu Terhadap Parameter Fisis Biji Pinang Hasil Pengeringan Menggunakan Alat Tipe Kabinet Dengan Limbah Tempurung Kelapa Sebagai Sumber Panas. Jurnal Ilmu Fisika, 8(1), 38-44.

Krisman, K., Erwin, E., Hamdi, H., \& Emrinaldi, T. 2019. Produksi ikan asin dengan menerapkan teknologi pengeringan berbasis energi biomassa yang ramah lingkungan untuk meningkatkan ekonomi masyarakat di Desa Buluh Cina, Kecamatan Siak Hulu, Kampar. Unri Conference Series: Community Engagement, 1, 333-340.

Kornita, S.E. Yusuf, Y., dan Mayes, A., 2009. Analisis perdagangan komoditas perikanan di Kecamatan Bantan Kabupaten Bengkalis. Jurnal Ekonomi, 17(2).

Sumarsono, M. 2006. Analisa Performansi Kolektor Udara Pada Sistim Pengering Kayu Dengan Sumber Energi Hibrid Surya-Biomassa. Jurnal Teknologi Energi, 1(3). 